\title{
Studies on Mechanical Properties of Composite Materials Based on Thermo Modified Timber
}

\section{Analiza mehaničkih svojstava kompozitnih materijala proizvedenih od toplinski obrađenog drva}

\author{
Original scientific paper • Izvorni znanstveni rad \\ Received-prispjelo: 20. 2. 2012. \\ Accepted-prihvaćeno: 15. 11. 2012. \\ UDK: $630 * 812.7 ; 630 * 862 ; 674.04$ \\ doi:10.5552/drind.2013.1206
}

\begin{abstract}
The paper presents the studies of the possibility of using thermo modified wood during the production process of composite materials. According to the studies, the influence of high-temperature processing of raw wood, without access of air oxygen, shows the feasibility of using this type of processing in the production of woodcement composites to improve their performance properties. It is established that high-temperature pre-treatment significantly reduces the "cement poisons", such as water-soluble sugars in wood, reduces water absorption and swelling pressure development and, consequently, creates a composite material resistant to use under conditions of high humidity. A mathematical model was formulated that allows the determination of the ultimate strength of wood-concrete composite made from thermo modified wood particles according to the treatment temperature of the wood chips and the mixture ratio.
\end{abstract}

Key words: thermo modification, wood-filled composite, wood-concrete

\begin{abstract}
SAŽETAK • U radu se iznose rezultati istraživanja mogućnosti uporabe toplinski obrađenog drva za proizvodnju kompozitnih materijala. Istraživanja su pokazala da utjecaj visoke temperature toplinske obrade na drvo, bez prisutnosti kisika, omogućuje primjenu tako obrađenog drva u proizvodnji drvo-cementnih kompozita kako bi se poboljšala njihova svojstva. Utvrđeno je da prethodna obrada drva visokim temperaturama znatno smanjuje “cementne otrove” kao što su vodotopljivi šećeri u drvu, smanjuje upijanje vode i pojavu tlaka bubrenja, što omogućuje proizvodnju kompozitnog materijala koji je otporan pri uporabi u uvjetima visoke vlažnosti. Izrađen je matematički model koji omogućuje određivanje čvrstoće kompozita drvo-beton proizvedenoga od topliski modificiranih drvnih čestica u ovisnosti o temperaturi obrade iverja i omjeru mješavine drva i betona.
\end{abstract}

Ključne riječi: toplinska modifikacija, kompoziti od drva, kompozitni materijal drvo-beton

\footnotetext{
${ }^{1}$ Authors are professors at Department of Architecture and Design of Forest Products, FSBEI HPE Kazan National Research Technological University, Kazan, Russian Federation. ${ }^{2}$ Authors are professor and assistant at Department of Wood Processing, Faculty of Forestry and Wood Sciences, Czech University of Life Sciences in Prague, Czech Republic.

Autori su profesori Odsjeka za arhitekturu i dizajn proizvoda od drva, FSBEI HPE Kazansko nacionalno znanstveno tehnološko sveučilište, Kazan, Ruska Federacija. ${ }^{2}$ Autori su profesor i asistentica Odjela za obradu drva Fakulteta šumarstva i drvne tehnologije, Sveučilište bioloških znanosti u Pragu, Češka Republika.
} 


\section{INTRODUCTION}

\section{UVOD}

In recent years, there has been an increasing interest in timber and related products for use in construction, because of the possibility of obtaining foundamentally new materials with improved properties - composites. However, besides good properties (low average density, ease of processing, in particular, with fragmentation, etc.), wood chips also have negative qualities that make it difficult to obtain a material of high strength (Nanazashvily, 1974, 1981, 1984, 1990): high chemical aggressiveness, significant volumetric humidity of deformation and development of swelling pressure, a significant anisotropy, high permeability, low adhesion relative to the cement stone; considerable resilience during compaction of the mixture.

Traditional methods of wood modification (mechanical, chemical) have practically exhausted its possibilities. So it is urgent to find and develop new technologies based mostly on physical impacts, for example high temperature without air access, which would improve the quality and competitiveness of wood products. At the same time, the well known technology of thermal wood modification (Pat. EP-0759137, 1998), which increases longevity (Jamsa and Viitaniemi, 2001), reduces water absorption and swelling of the wood (Calonego et al., 2010). However, in the manufacture of composite materials, this technology is still unexplored.

Therefore, the present study had the following objectives: to assess experimentally the effect of high temperature on physical properties, chemical composition and structure of the wood filler, and to develop recommendations for improving the manufacturing processes of wood-composite materials that enhance their mechanical properties.

\section{MATERIAL AND METHODS} 2. MATERIJAL I METODE

This paper presents the results of the properties of composite material, in which heat-treated wood particles are used as a filler, and cement is used as a binder (Razumov et al., 2009, 2010). Sheets of birch veneer were used to get wood particles of specific sizes. These sheets were cut and split into three fractions of wood chips with an average length of 20,40 and $60 \mathrm{~mm}$ and a width ranging between 3 and $5 \mathrm{~mm}$. For the manufacture of modified wood, concrete chips were used: not subjected to special types of processing; heat treated at various temperatures prior to the termination of mass loss.

Thus-obtained wood chips were subjected to heat treatment in the temperature range $160-220{ }^{\circ} \mathrm{C}$ prior to the termination of mass loss in the experimental vacuum-contact apparatus, consisting of a sealed chamber for heat treatment connected with the vacuum pump (Khasanshin et al., 2010). Heat supply to the treated material was carried out by contact method with the help of thermo joining surfaces, normally a perforated metal plate heated by filaments and thermally insulated on the side opposite to the processed material with porous and moisture-breathable material (Safin et al., 2009, 2010). While conducting thermo modification, the wood particles were heated to a certain temperature (between 160 and $220^{\circ} \mathrm{C}$ ) and weighed every half an hour. The end of treatment was determined when the decrease of the sample mass (wood chips), weighted at an interval of 30 minutes, was less than $3 \%$.

Treated in this way, wood chips were used for studying the properties of thermo modified wood as a filler in composite materials, as well as for the manufacture of wood-filled composite - wood concrete - in order to further study its mechanical properties.

Studies of thermo modified wood as a filler in composite materials were carried out based on the following main factors: wetting property - in composite compositions such as "wood - mineral binding substance" determines adhesive interaction between timber and binder; the content of water-soluble reduced substances - affects the cementation of mineral binders, water-absorption and swelling pressure - determines the development of internal-strain during operation of the composite and, hence, its longevity.

Studies on wetting property of thermo modified wood were conducted by determining the contact angle at rest drops using a microscope equipped with an optical graphometer. The study on the content of soluble reducing substances and the development of swelling pressure were carried out by Russian State standards 19222-84, and 21312-75 with the help of titrimetric analysis.

Samples of wood concrete were made by mixing wood chips (wood : cement in accordance with the weight $1: 3,1: 2.5,2: 3)$ and cement mark 400 and water (water to cement ratio varied between 1:4 to $1: 1$ at intervals of 0.05 ) in certain proportions according to the experiment plan. These samples were molded in metal containers with the dimensions 100x100x100 mm and the mixture was sealed with the help of using the vibrating table for a previously defined time sufficient to complete the mixture shrinkage - $7 \mathrm{~min}$. The molded mixture was kept in containers for a day and then it was removed and conditioned in the premises for 30 days to reach full cementation.

After that, samples were subjected to cyclical wetting and drying in order to study the negative impact of the swelling pressure of wood filler. At the same time, the samples were immersed in water at room temperature for 5 days, and dried in an oven at $105{ }^{\circ} \mathrm{C}$ to constant weight. There were 20 "wetting-drying" cycles, after which changes occurred in maximum compression strength.

In order to study composite materials based on the strength of compression, the Sz-5-1 testing machine was used. The purpose of these pilot studies was to investigate the variation of the strength characteristics of the composite material due to changes in the physical-chemical and physical-mechanical properties of wood filler in high-temperature heat treatment. 


\section{RESULTS AND DISCUSSION}

\section{REZULTATI I RASPRAVA}

Results of experimental studies of thermo modified wood as a filler for composite materials are shown in Figures 1-3. Graphic analysis of the dependences in Figure 1 shows the reduction of the wetting property of wood with the increase of the treatment temperature, which may have a negative effect on the adhesive interaction between the wood and binder, meaning that creating a mixture requires a more thorough mixing of the components. However, the result of research of the content of water-soluble substances showed that ther- mo modification causes reduction of these substances, by more than $40 \%$, which in turn is beneficial to the strength of composite materials.

The results of experimental studies of thermo modified wood in the development of swelling pressure are shown in Figure 2. The graphs show that with the increase of the treatment temperature, swelling pressure of wood is significantly reduced, which applied to the wood-filler is a positive factor, and can lead to the improvement of performance properties of wood concrete.

As a result of studies for determining the crush strength of wood concrete made from heat-treated wood particles that were subjected to 20 wetting and

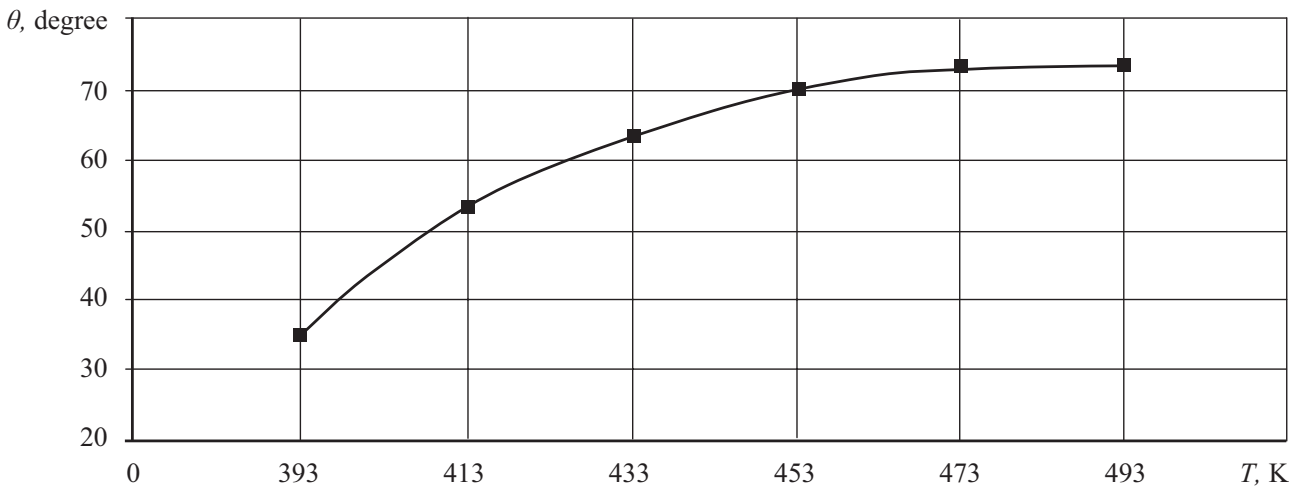

Figure 1 The dependence of the contact angle on the processing temperature

Slika 1. Ovisnost kontaktnog kuta o temperaturi obrade

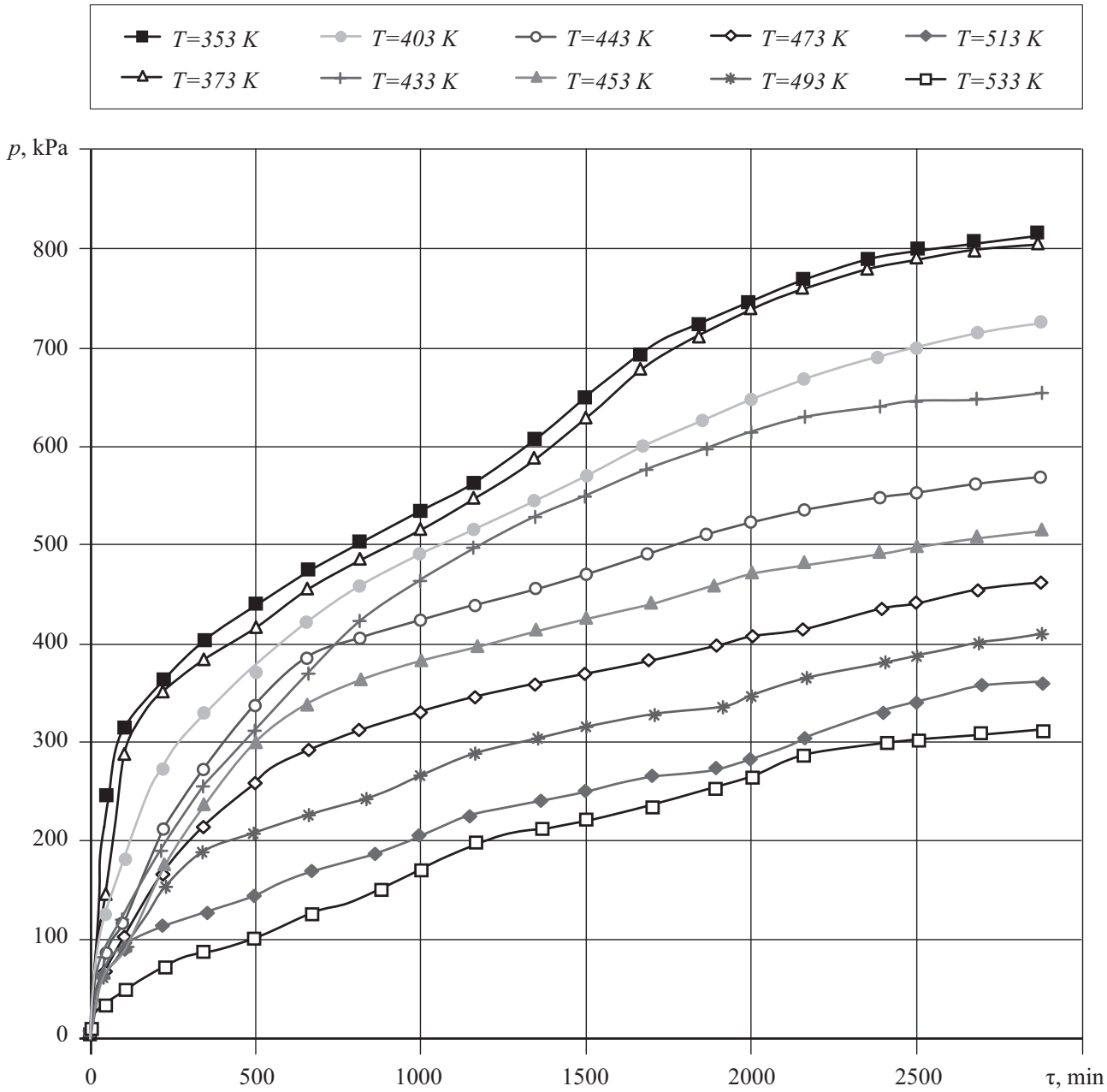

Figure 2 The development of swelling pressure of modified wood treated at different temperatures

Slika 2. Razvoj tlaka bubrenja u modificiranom drvu pri različitim temperaturama obrade 


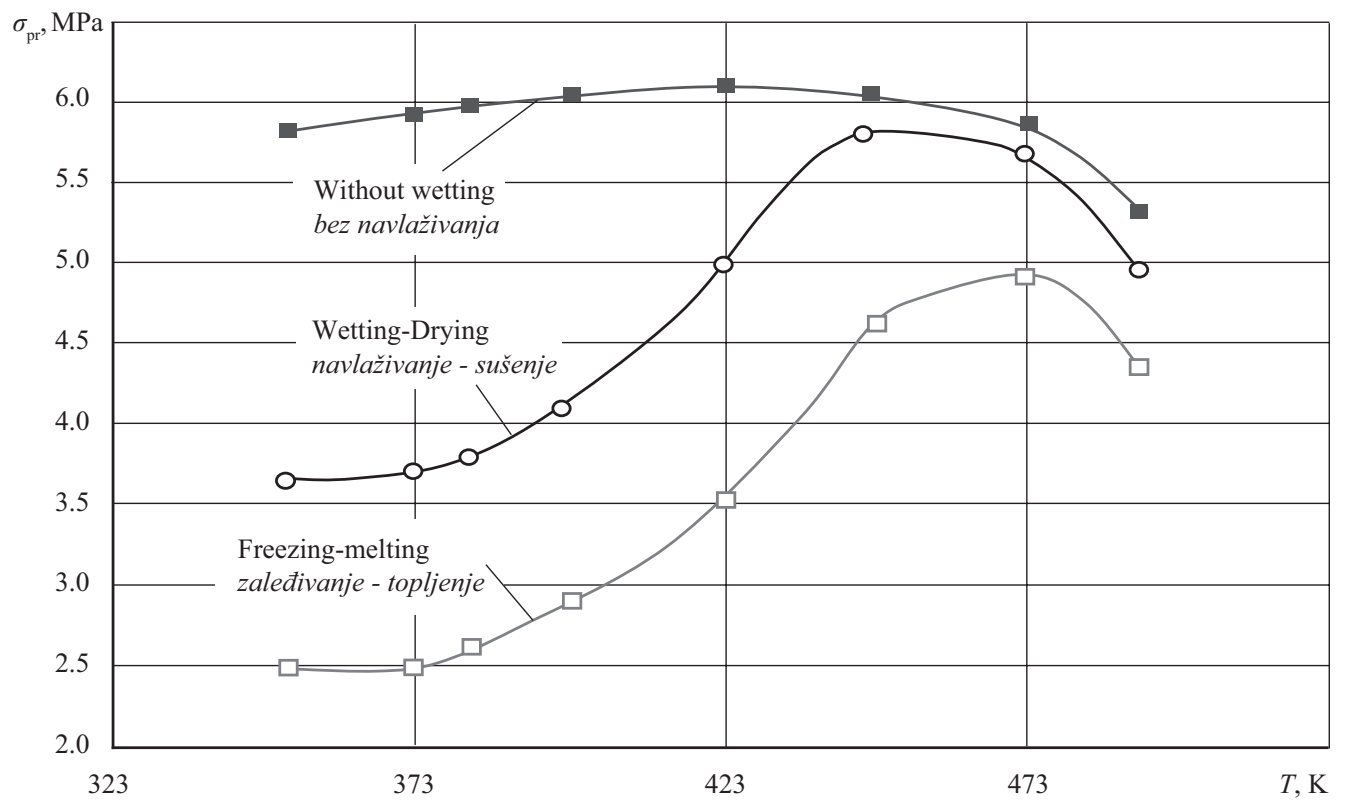

Figure 3 Maximum compression strength of wood concrete samples made from heat-treated wood particles

Slika 3. Maksimalna tlačna čvrstoća uzoraka kompozita drvo-beton izrađenih od toplinski obrađenih drvnih čestica

drying cycles, and 20 freezing and thawing cycles, graphical dependence was obtained as presented in Figure 3. The graph shows that the preliminary thermo modification of wood particles during the production process of wood concrete can significantly improve the performance properties of this material by heat impacts in the range 455 - $475 \mathrm{~K}$ and, consequently, expand the range of its use. To be specific, wood concrete may be used under conditions of high humidity.

During experimental studies, the influence was also determined of mixing ratio on the mechanical properties of wood concrete. Thus, as a result of processing the experimental data, it has been found that the thermal treatment of the chip reduces watercement ratio (Figure 4), which can be explained by a significant reduction in water absorption of thermo modified wood particles as compared to the untreated ones. As a result of reconnaissance experiments, it was determined that the optimum water-cement ratio for heat-treated fillers was 0.45 .

Figure 5 shows the dependence of ultimate strength in compression of wood concrete on the length of the chip. The analysis of the obtained dependence shows that the increase of compression strength occurs with the decrease of the size of wood filler, as a result of the increased contact area between wood particles and of increased thickness of the binder (cement) layer.

Processing the experimental results, the dependence of ultimate strength of the composite material in compression on the ratio of the mass of wood chips to the mass of the mineral-binder was obtained. The resulting dependence presented in Figure 6 shows a decrease in strength with the increase of wood content in relation to the binder.

As planned, based on the results of the experiment a mathematical model was formulated for wood-com-

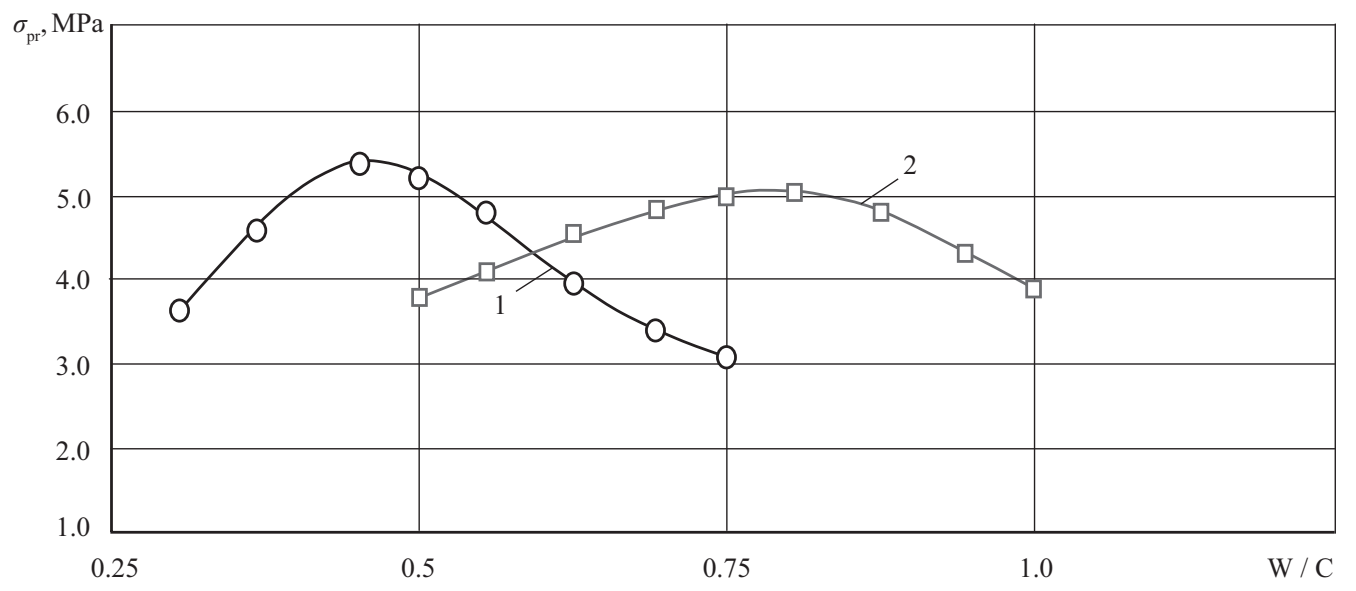

Figure 4 Changes in maximum compression strength of wood concrete depending on the "water-cement" ratio: 1 - filler, heat-treated at $T=473 \mathrm{~K} ; 2$ - filler, no specific treatment done

Slika 4. Promjene maksimalne tlačne čvrstoće kompozita drvo-beton u ovisnosti o omjeru vode i cementa: 1 - punilo toplinski obrađeno pri $T=473 \mathrm{~K} ; 2$ - punilo toplinski neobrađeno 


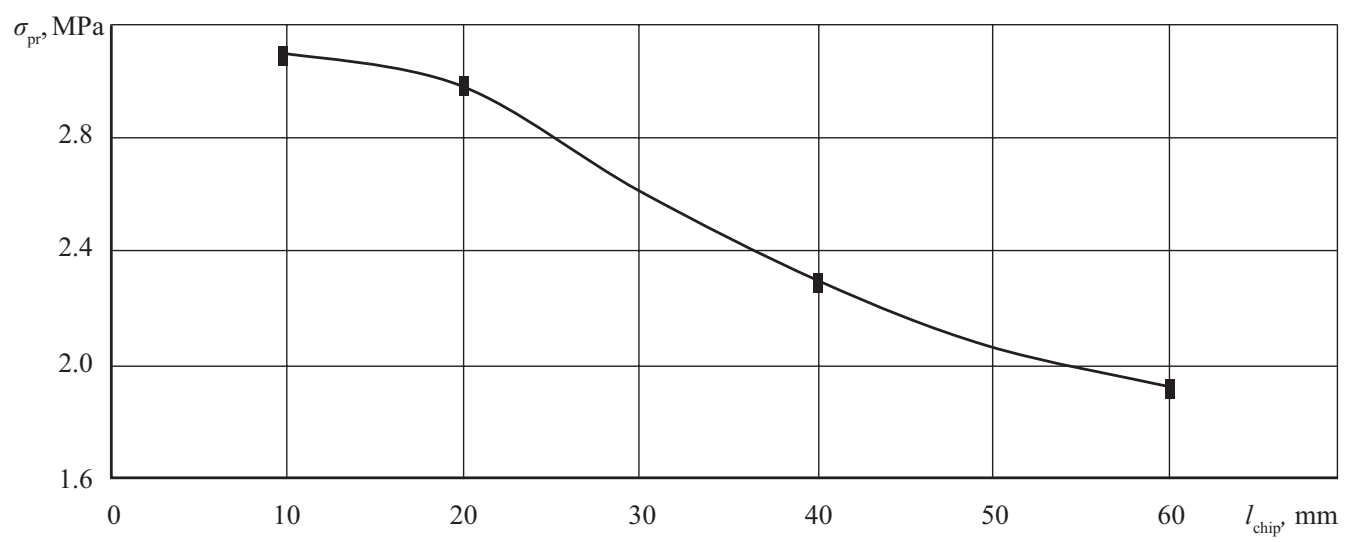

Figure 5 Maximum compression strength of wood concrete depending on the length of the chip

Slika 5. Maksimalna tlačna čvrstoća kompozita drvo-beton u ovisnosti o duljini iverja

posite material, which allows predicting the ultimate strength of the composite in compression, depending on the amont and treatment regime of wood filler. The obtained empirical equations show that the compression strength of wood concrete depends on use conditions, processing time and the amount of cement per surface unit of wood chips (thickness of cement rock).

The average value of the binder layer is determined by the relation of the initial components in the composition, density of packing, the nature and properties of the chip and binder, as well as the size and magnitude of the specific surface area of the filler. Hence, the thickness of interlayer cement in the contact zone in the structure of wood concrete can be approximately determined by using the empirical expression:

$$
\delta=\frac{\alpha \cdot C \cdot K}{H \cdot S_{\mathrm{sp}} \cdot \rho_{\mathrm{c}}},
$$

Where $C$ and $H$ - consumption of cement and hogged chips per $1 \mathrm{~m}^{3}$ of wood concrete, $\mathrm{kg}$; $\alpha$ - coefficient taking into account the technological properties of wood-cement composites; $\rho_{\mathrm{c}}$ - the average density of cement, $\mathrm{kg} / \mathrm{m}^{3} ; S_{\mathrm{sp}}$ - specific surface of hogged chips, $\mathrm{m}^{2} / \mathrm{kg} ; K$ - the output of cement slurry of normal thickness, part of the whole. In our studies, the coefficients have the following values: $\alpha=1.25, K=0.5$.

The specific surface area of wood particles $S_{\mathrm{sp}}$ of the filler can be determined by a formula that takes into account the surface edges and ends:

$$
S_{\mathrm{sp}}=\frac{2}{\rho} \cdot\left(\frac{1}{\ell}+\frac{1}{b}+\frac{1}{a}\right),
$$

Where $\rho$ - the average wood density in $\mathrm{g} / \mathrm{cm}^{3} ; l$, $b, a$ - the length, width, thickness, respectively, of a single particle of the chip in $\mathrm{cm}$.

As a result of analytical and experimental studies, the expressions were obtained for the ultimate strength of wood concrete made from thermally modified wood particles depending on the conditions of exploitation:

- When operating in dry conditions (without wetting):

$$
\begin{aligned}
\sigma_{\text {w/owetting }}= & 1.3453+0.0859 \cdot T-0.0012 \cdot T^{2}+ \\
& +6.8085 \cdot 10^{-6} \cdot T^{4}+675 \cdot \delta+50000 \cdot \delta^{2}
\end{aligned}
$$

- When operating in conditions of variable humidity (after 20 cycles of "wetting-drying")

$$
\begin{aligned}
\sigma_{\text {wwetting }}= & \frac{3.452-0.0498 \cdot T+0.0002 \cdot T^{2}-}{1-0.0122 \cdot T+} \\
& \frac{-2.6664 \cdot 10^{-7} \cdot T^{3}+5.7851 \cdot \delta+30290.544 \cdot \delta^{2}}{+3.5372 \cdot 10^{-5} \cdot T^{2}+30.3762 \cdot \delta}
\end{aligned}
$$

Thus, the resulting mathematical model allows predicting the ultimate strength for wood concrete in compression depending on the amount and treatment regime of wood filler.

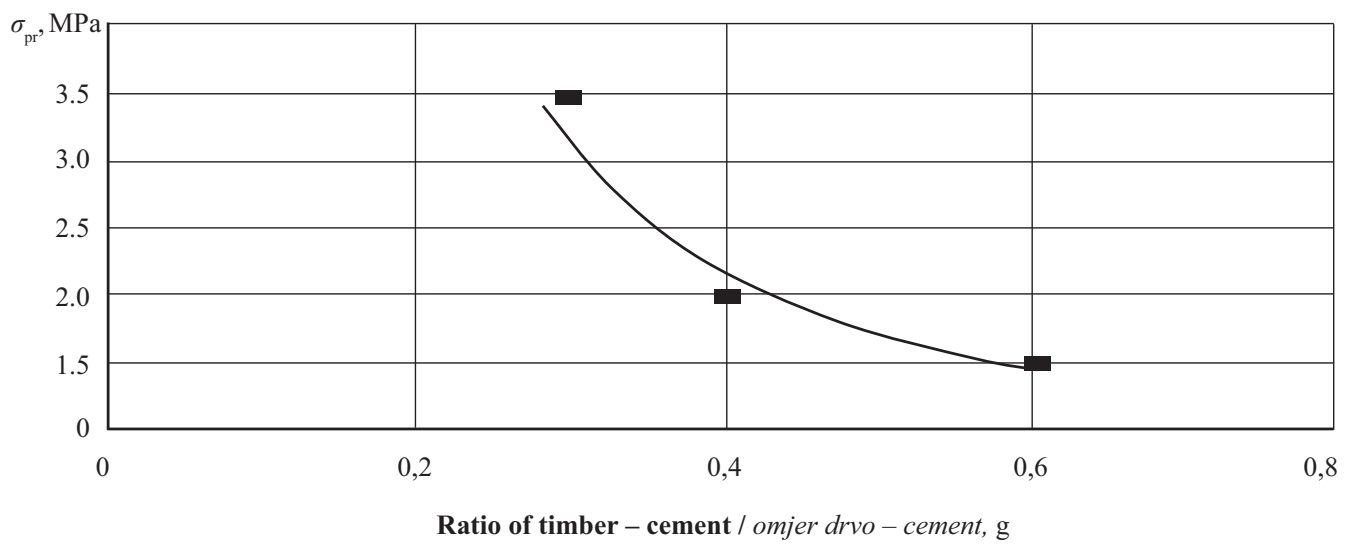

Figure 6 Maximum compression strength of wood concrete samples depending on "wood - cement" ratio Slika 6. Maksimalna tlačna čvrstoća kompozita drvo-beton u ovisnosti o omjeru drva i cementa 


\section{CONCLUSION}

\section{ZAKLJUČAK}

As a result of experimental studies, based on the basic properties of composite materials made from thermo modified wood and mineral binders, it was determined that this type of processing of wood chips could be used to improve the performance properties of the composite material. Thermal effects, in the temperature range $180-210{ }^{\circ} \mathrm{C}$, significantly improve the performance properties of wood concrete, increasing its resistance to moisture. Wood concrete made from wood particles, heat-treated without oxygen, is recommended to use when operating in wet conditions.

\section{REFERENCES}

5. LITERATURA

1. Calonego, F. W.; Severo, E.T.D.; Ballarin, A.W., 2010: Physical and mechanical properties of thermally modified wood from E. grandis. Eur. J. Wood Prod. DOI 10.1007/s00107-011-0568-5 http://dx.doi.org/10.1007/s00107-011-0568-5.

2. Jamsa, S.; Viitaniemi, P., 2001: Heat treatment of wood: better durability without chemicals. In: Rapp, A.O. Review on heat treatment of wood. In: Special seminar: environmental optimization of wood protection, Antibes, France. Proceedings, Antibes; COST ACTION E 22:21-26.

3. Nanazashvili, I. KH., 1974: Production of wood-concrete from waste wood / I.KH. Nanazashvili; M.K. Mardanov // Background information of COSTI of Ministry of industrial engineering USSR, p. 4-42.

4. Nanazashvili, I. KH., 1981: The effect of swelling pressure of wood filler made of larch and other conifers in the processes of structure formation of wood concrete / I. KH. Nanazashvili // Effective methods and equipment for precast concrete construction in the rural engineering: Works of CSRIE Pselstroy. M., p. 79-84.

5. Nanazashvili, I. KH., 1984: Wood-concrete is an effective construction material. / I.KH. Nanazashvili. M., 122 p.

6. Nanazashvili, I.KH. 1990: Construction materials from wood-cement composite. / I.KH. Nanazashvili. $-2^{\text {nd }}$ edition, revised and amended. - L.: Stroyizdat, 415 p.

7. Pat. EP-0759137 (SE, DK, NL, GB, FR, DE), 1998: Method for processing of wood at elevated temperatures. VTT (VIITANIEMI, P., RANTA-MAUNUS, A., JAMSA, S. and Ek, P). Appl. EP95918005, 11.5.1995. Publ.4.2.1998. 10 p.
8. Safin, R.R.; Belyakov, E.A.; Khasanshin, R.R.; Razumov, E.Y. 2010: Imitation of oak wood by means of thermo modification. Design. Materials. Technology. 3 (14): 95-98.

9. Razumov, E.Y.; Kainov, P.A.; Safin, R.R.; Khasanshin, R.R., 2010: The study of chemical composition of wood subjected to thermo modification by IR spectrometer. // Bulletin of the Kazan Technological University, 9.

10. Razumov, E.Y., 2009: Composite materials based on modified sawdust treated with RF plasma /E.Y. Razumov; R.R. Safin; L.I. Aminov; R.R. Khasanshin // Wood working industry, 1: 24-26.

11. Safin, R.R., 2009: The study of vacuum-conductive process of modifying the heat treatment of wood / R.R. Safin; M.K. Gerasimov; D.A. Akhmetova; E.Y. Razumov // Wood-working industry, 3: 9-11.

12. Razumov, E.Y. 2009: Production of Cellulose Fibre, with the addition of wood pulp / E.Y. Razumov; E.I. Baigildeeva; V.A. Kashapov; L.G. Golubev // Wood-working Industry, 4: 9-10.

13. Safin, R.R., 2009: Plant for processing waste wood industries / Установка для переработки отходов древесных производств / R.R. Safin; A.E. Voronin; E.Y. Razumov; A.T. Sabirov // "Issues of modern science and practice" V.I. Vernadsky University, 5(19): 82-87.

14. Razumov, E.Y., 2009: Apparatus for thermal treatment of waste /E.Y. Razumov; R.R. Safin; M.A. Taimarov; K.Kh. Gilfanov // "Issues of modern science and practice" V.I. Vernadsky University, 5(19): 95-101.

15. Khasanshin, R.R., 2010: Thermo treatment of wood in the flue gases medium / R.R. Khasanshin; E.Y. Razumov; R.R. Safin; N.A. Oladishkina// Newsletter of Moscow State Forest University "Forest newsletter", 4 (73): 95-99.

16. Razumov, E.Y., 2010: Mathematical modeling of thermo treatment process/ E.Y. Razumov; N.A. Oladishkina; R.R. Safin // Proceedings of the XXIIIth International scientific conference "MMTT-23", SSTU, Saratov, p. 38-40.

\section{Corresponding address:}

\section{Professor EVGENY Y. RAZUMOV}

Department of Architecture and Design of Forest Products

Kazan National Research Technological University

420015, Russia, Kazan, K. Marx St., 68

RUSSIAN FEDERATION

e-mail: evgeny.razumov2011@yandex.ru 